Article

\title{
Effects of Melatonin on Antioxidant Capacity in Naked Oat Seedlings under Drought Stress
}

\author{
Wenying Gao, Yujing Zhang, Zheng Feng, Qingqing Bai, Jinjin He and Yingjuan Wang * \\ State Key Laboratory of Biotechnology of Shannxi Province, Key Laboratory of Resource Biology and \\ Biothchnology in Western China (Ministry of Education), College of Life Science, Northwest University, \\ Xi'an 710069, China; 201620849@stumail.nwu.edu.cn (W.G.); 201520869@stumail.nwu.edu.cn (Y.Z); \\ f7616287@163.com (Z.F.); 201731801@stumail.nwu.edu.cn (Q.B.); hjj18691403985@163.com (J.H.) \\ * Correspondence: wangyjbio@nwu.edu.cn; Tel.: +86-186-2932-6118
}

Received: 30 May 2018; Accepted: 27 June 2018; Published: 29 June 2018

\begin{abstract}
Melatonin ( $N$-acetyl-5-methoxytryptamine, MT) is a molecule with pleiotropic effects including antioxidant activity, regulated plant growth, development, and reduced environmental stress in plants. However, only a few studies have analyzed the effect of exogenous MT on drought stress in naked oat seedlings. Therefore, in this study, we studied the effects of exogenous MT on the antioxidant capacity of naked oat under drought stress to understand the possible antioxidant mechanism. The results showed that a pretreatment of $100 \mu \mathrm{M}$ MT reduced the hydrogen peroxide $\left(\mathrm{H}_{2} \mathrm{O}_{2}\right)$ and superoxide anion $\left(\mathrm{O}^{2-} \bullet\right)$ contents. MT also enhanced superoxide dismutase (SOD), peroxidase (POD), catalase (CAT), and ascorbate peroxidase (APX) activities in the leaves of naked oat seedlings under 20\% PEG-6000 drought stress. MT upregulated the expression levels of the mitogen-activated protein kinases (MAPKs) Asmap1 and Aspk11, and the transcription factor (TF) genes (except for NAC), WRKY1, DREB2, and MYB increased in drought with MT pretreatment seedlings when compared with seedlings exposed to drought stress alone. These data indicated that the MT-mediated induction of the antioxidant response may require the activation of reactive oxygen species (ROS) and MAPK, followed by triggering a downstream MAPK cascade such as Asmap1 and Aspk11, to regulate the expression of antioxidant-related genes. This study demonstrated that MT could induce the expression of MAPKs and TFs and regulate the expression of downstream stress-responsive genes, thereby increasing the plant's tolerance. This may provide a new idea for MT modulation in the regulation of plant antioxidant defenses. These results provide a theoretical basis for MT to alleviate drought stress in naked oat.
\end{abstract}

Keywords: drought stress; melatonin; naked oat seedling; antioxidant

\section{Introduction}

Naked oat (Avena nuda L.) is an annual herbaceous crop in the family Poaceae. Naked oat is a high nutritional value cereal [1] and is a unique food crop in Chinese alpine regions. Naked oat is extremely nutritious and medically valuable, and it is also used as both a food and a grass for animal husbandry production [1-3]. However, abiotic stressors directly limit the growth of naked oat, which restricts the effective use and development of the plant [4].

Abiotic stress greatly limits the growth and yield of plants. With the increase in global temperatures, the effect of drought stress is particularly prominent, and has become the main environmental factor limiting the growth and development of plants worldwide [5]. In general, drought stress causes a series of physiological and biochemical reactions such as stomatal closure, decreased chlorophyll content, decreased transpiration, and reduced antioxidant capacity [6]. Drought stress increases the production of ROS such as $\mathrm{H}_{2} \mathrm{O}_{2}$ and $\mathrm{O}^{2-} \bullet$. Membrane lipid peroxidation is triggered 
when the balance between ROS accumulation and the free radical scavenging systems is disrupted, causing damage to the membrane system and leading to an imbalance in plant metabolism [7]. Mechanisms have developed in plants to combat adverse conditions (the main factor that limits plant productivity), which can prevent harmful damage [5], and the antioxidant system is one of the best ways plants resist stress. Plant antioxidant enzyme systems, such as SOD, POD, CAT, and APX scavenge ROS [8]. Similarly, ROS also activates or induces stress-related factors such as MAPK and TF, which further act as inducers or activators to activate response gene expression, thereby enhancing stress tolerance [9]. The increased expression and activity of these systems help maintain normal cellular metabolism and improve plant resistance to the stressor. Changes in external conditions activate the plant's internal antioxidant system to maintain and balance normal physiological reactions, which directly affect the plant's ability to resist adversity [10].

Melatonin ( $\mathrm{N}$-acetyl-5-methoxytryptamine, MT) is a small molecule neuroendocrine hormone. In animals, MT functions as a regulator of circadian rhythms [11], sleep, and the immune system [12], and has antitumor [13] and antioxidant activities [14-17]. MT was identified in plants for the first time by Dubbels et al. [18] and Hattori et al. [19]. Thereafter, MT has been found in a variety of plant species [20-23] with various biological functions such as the morphogenesis of organs [24], regulation of circadian rhythms, and, in flower development, the promotion of photosynthesis, fruit maturation, protection of chlorophyll $[25,26]$, and delaying leaf senescence $[27,28]$. MT may also have antioxidant effects in plants. The antioxidant effects of MT have been confirmed in apple [29], rice [30], and grape [31]. Several studies have reported that MT enhances drought resistance in crops [32,33]. However, there is little research on antioxidant protection in naked oat. Therefore, in the present study, naked oat seedlings under drought stress were treated with MT to study the effects of MT on antioxidant enzyme activities and the expression levels of related resistance genes in leaves. The results will provide a basis for understanding the MT response mechanism during plant drought.

\section{Results}

\subsection{Effect of Spraying $100 \mu M$ MT on Leaves of Naked Oat Seedlings under Drought Stress}

The growth of naked oat seedlings was inhibited by drought stress, and $100 \mu \mathrm{M}$ MT promoted seedling growth (Figures 1 and 2). Under drought stress, plant height, stem thickness, plant fresh weight, and plant dry weight of naked oat seedlings were all inhibited, but that response was alleviated by adding MT. The increases for drought with MT-pretreated plants were $2.32 \%$ for plant height, $14.55 \%$ for stem thickness, $10.74 \%$ for plant fresh weight, and $7.57 \%$ for plant dry weight when compared with the drought group, respectively.

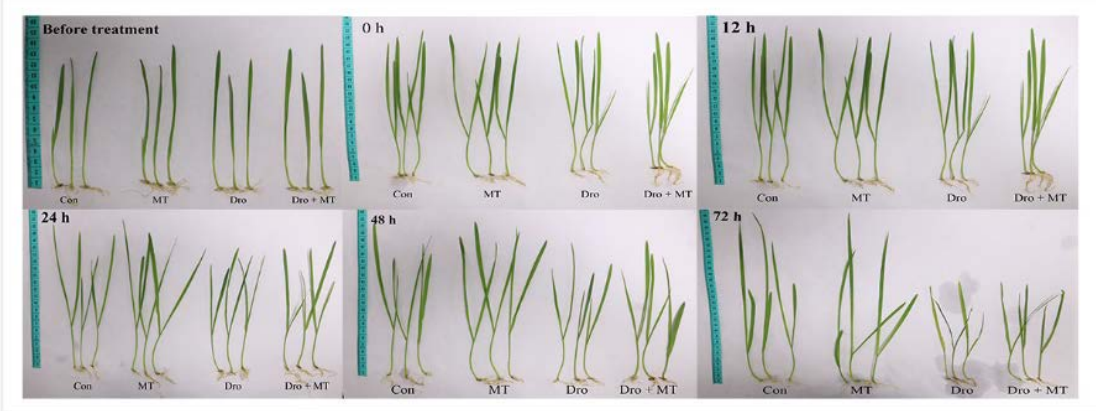

Figure 1. The performance of naked oat seedlings under normal and drought stress conditions. Con: seedlings grown in half-strength Hoagland solution; MT: seedlings pretreated with $100 \mu \mathrm{M}$ MT, grown in half-strength Hoagland solution; Dro: seedlings grown in half-strength Hoagland solution plus 20\% PEG-6000; Dro + MT: seedlings pretreated with $100 \mu \mathrm{M}$ MT, grown in half-strength Hoagland solution plus 20\% PEG-6000. Photographs were taken before melatonin pretreatment, and after drought stress with melatonin pretreatment at $0,12,24,48$, and $72 \mathrm{~h}$. 

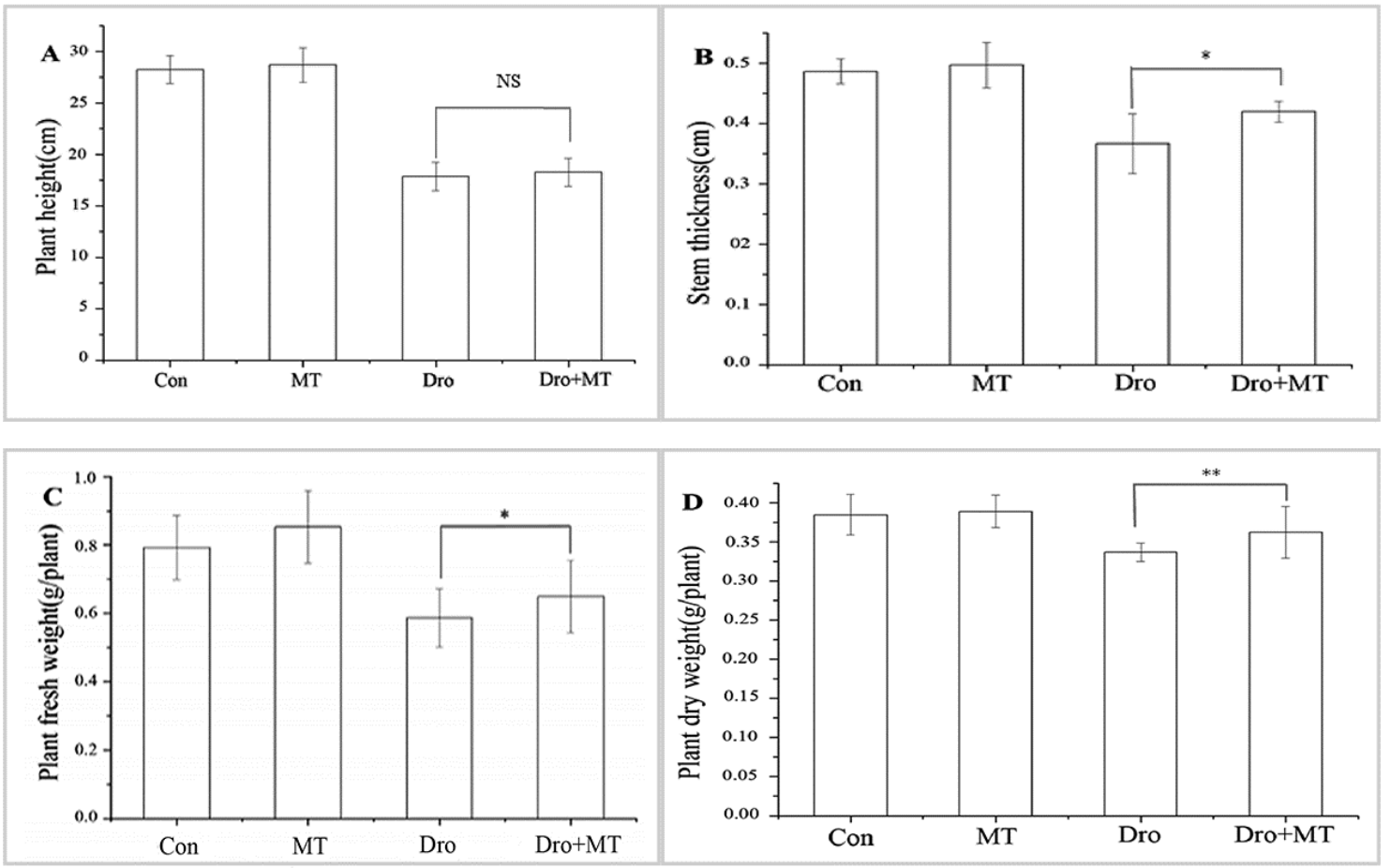

Figure 2. Effect of $100 \mu \mathrm{M}$ melatonin on growth of naked oat seedlings. (A) Plant height; (B) Stem thickness; (C) Plant fresh weight; (D) plant dry weight. Values represent mean \pm standard deviation $(n=3)$. Significant difference between drought with pretreatment MT and drought-treated. Asterisks; ${ }^{*},{ }^{* *}$ indicate $p$ values, $<0.05$ and 0.01 , respectively. NS; No significance. Control, untreated, Con; melatonin pretreatment, MT; drought, Dro; drought plus $100 \mu \mathrm{M}$ melatonin pretreatment, Dro + MT.

\subsection{Effect of MT Pretreatment on Antioxidant Enzyme Activities of Naked Oat Seedlings under Drought Stress}

Drought stress and the application of exogenous MT affected the antioxidant enzyme activities of the naked oat seedlings (Figure 3). The activities of SOD, POD, CAT, and APX in naked oat seedlings were significantly induced under drought stress. However, the $100 \mu \mathrm{M}$ exogenous MT pretreatment increased the antioxidant enzyme activities of naked oat seedlings. When the stress duration was 1 day, 2 day, and 3 day, the average activities of SOD, POD, CAT, and APX significantly $(p<0.05)$ increased by $110.41 \%, 34.29 \%, 26.14 \%$, and $10.35 \%$, respectively, after imposing drought stress and the $100 \mu \mathrm{M} \mathrm{MT}$ pretreatment when compared with the drought group. The data showed that exogenous MT increased the activities of the major antioxidant enzymes in naked oat seedlings under drought stress.

\subsection{Effect of MT Pretreatment on Changes in ROS in Naked Oat Seedlings under Drought Stress}

$\mathrm{H}_{2} \mathrm{O}_{2}$ and $\mathrm{O}^{2-}$ • are the two main forms of ROS produced under stress conditions [34]. $\mathrm{H}_{2} \mathrm{O}_{2}$ and $\mathrm{O}^{2-} \bullet$ contents increased in naked oat seedlings under drought stress and these increases were attenuated by pretreatment with MT (Figure 4). For instance, when compared with the control group, the $\mathrm{H}_{2} \mathrm{O}_{2}$ and $\mathrm{O}^{2-} \bullet$ contents in the naked oat seedlings significantly $(p<0.05)$ increased by $208.98 \%$ and $257.32 \%$ under drought stress, respectively. The accumulation of $\mathrm{H}_{2} \mathrm{O}_{2}$ and $\mathrm{O}^{2-} \bullet$ was alleviated by the MT pretreatment during drought stress, and decreased by $13.65 \%$ and $13.70 \%$, respectively.

\subsection{Effect of MT Pretreatment on MAPK Activity in Naked Oat Seedlings under Drought Stress}

The MAPK cascade is a signal transduction system that regulates plant growth and development in response to changes in stress [35]. Asmap1 and Aspk11 are MAPK genes of naked oat that were upregulated by drought stress. The expression levels of Asmap 1 and Aspk11 genes were higher under drought stress when compared to those in the untreated control (Figure 5). However, applying the MT 
pretreatment to leaves noticeably upregulated this response (Figure 5). The two MAPK genes were upregulated at $4 \mathrm{~h}, 12 \mathrm{~h}, 24 \mathrm{~h}, 36 \mathrm{~h}, 48 \mathrm{~h}$, and $72 \mathrm{~h}$, and the average relative expression levels of the genes were 6.30-fold and 29.45-fold higher than the drought stress alone group of seedlings.

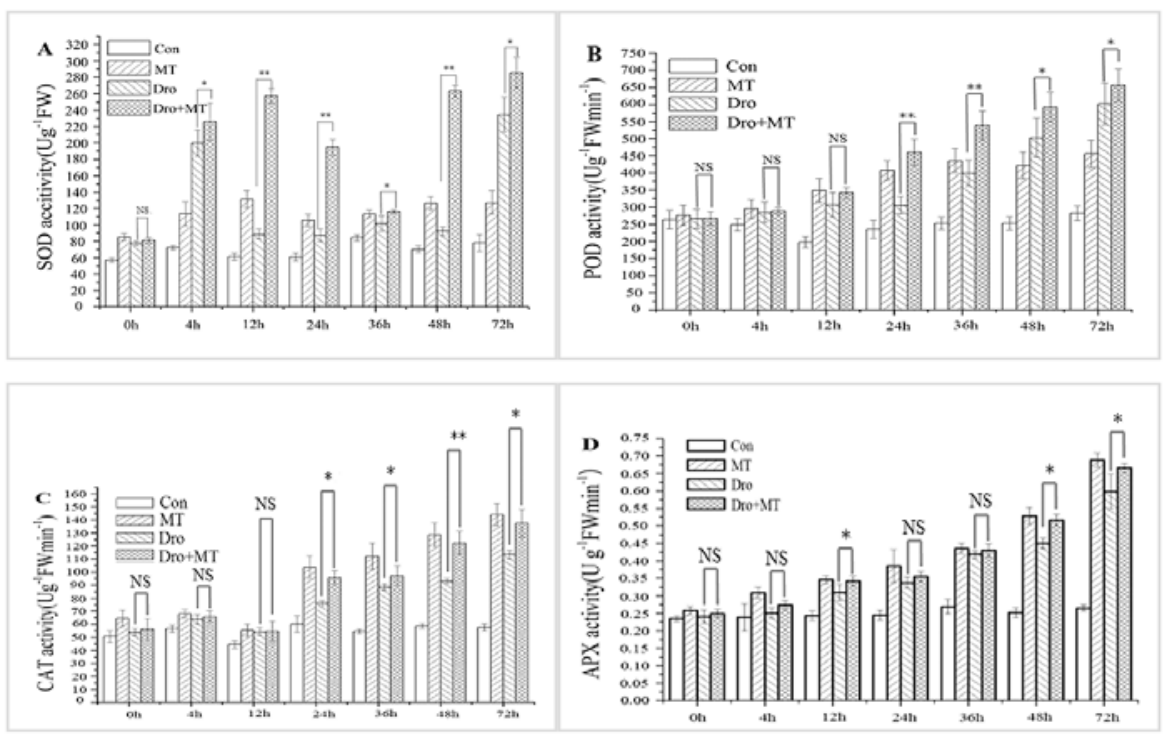

Figure 3. Effect of melatonin pretreatment on the antioxidant enzyme activities of naked oat seedlings under drought stress. (A) Super oxide dismutase (SOD); (B) peroxidase (POD); (C) catalase (CAT); (D) ascorbate peroxidase (APX). Values represent mean \pm standard deviation $(n=3)$. Significant difference between drought with pretreatment MT and drought-treated. Asterisks; ${ }^{*},{ }^{* *}$ indicate $p$ values, $<0.05$ and 0.01 , respectively. NS; No significance. Drought plus melatonin pretreatment at times $0,4,12,24,36,48$, and $72 \mathrm{~h}$.

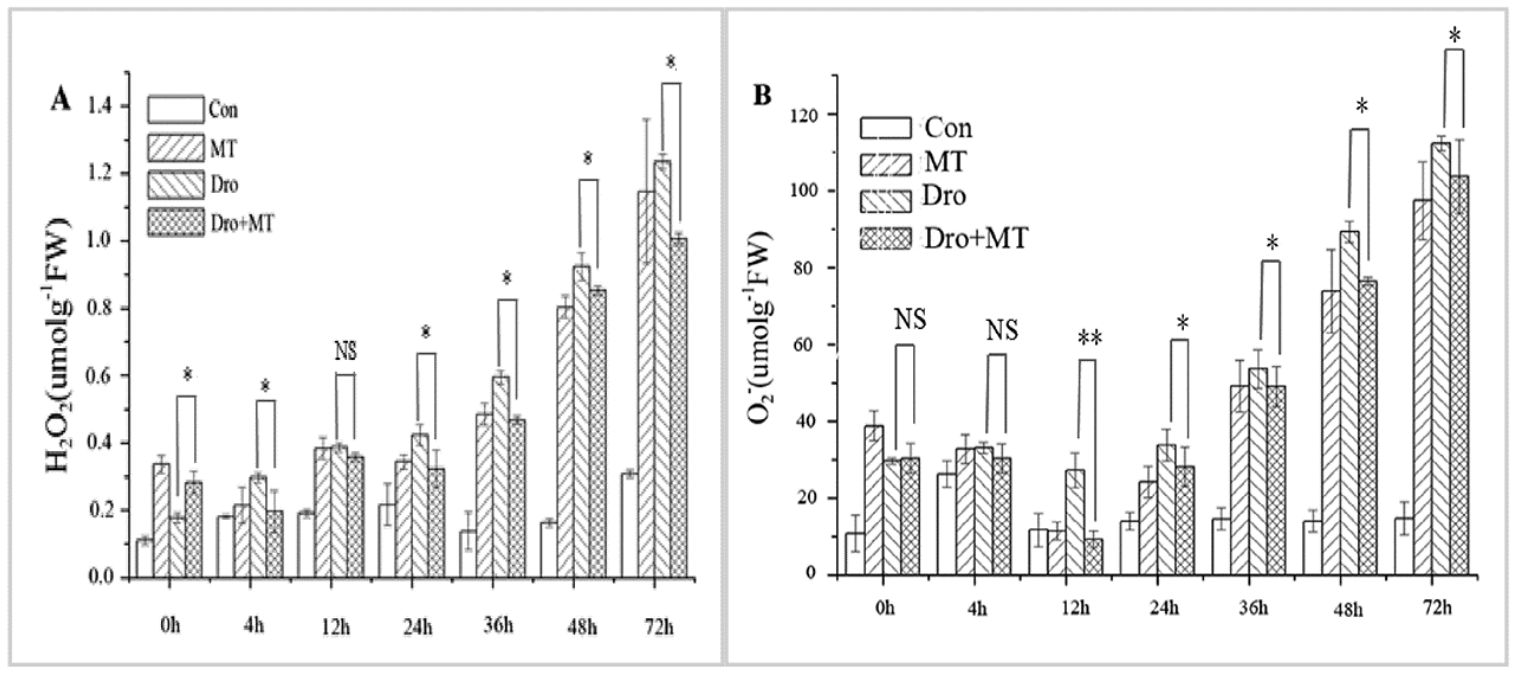

Figure 4. Effect of MT pretreatment on the changes of ROS in the naked oat seedlings under drought stress. (A) $\mathrm{H}_{2} \mathrm{O}_{2}$; and (B) $\mathrm{O}^{2-} \bullet$. Values represent mean \pm standard deviation $(n=3)$. Significant difference between drought with pretreatment MT and drought-treated. Asterisks; ${ }^{*},{ }^{* *}$ indicate $p$ values, $<0.05$ and 0.01 , respectively. NS; No significance. Drought plus melatonin pretreatment at times $0,4,12,24,36,48$, and $72 \mathrm{~h}$. 
2.5. Effect of MT Pretreatment on the Expression of Antioxidant-Related TF Genes in Naked Oat Seedlings during Drought Stress

TFs regulate the expression of eukaryotic genes. When drought and high temperature stress conditions occur, the plant stimulates the expression of TFs to regulate the expression of downstream responsive genes that enhance the resistance to stress [36]. TFs such as NAC, WRKY, DREB, and MYB, which are closely related to the stress response in plants, help plants regulate their activities in adverse environments [37]. Drought stress affected the expression of antioxidant-related TFs in naked oat seedlings during the experiment (Figure 6). In our study, the average expression levels $M Y B$ and WRKY1 in plants under drought stress were 0.74-fold and 2.00-fold higher than those in the control plants. However, after drought stress, the expression levels of $N A C$ and DREB2 decreased, and the expression levels were only 0.55-fold and 0.51-fold higher than those of the control group. Similarly, after drought with MT pretreatment, the expression levels MYB and WRKY1 were higher than those of the drought-treated plants. However, the MT pretreatment clearly alleviated the suppression of the $D R E B 2$ gene under drought stress in naked oat seedlings. The NAC gene appeared to be less affected under drought stress in the groups of naked oat seedlings with or without MT pretreatment.

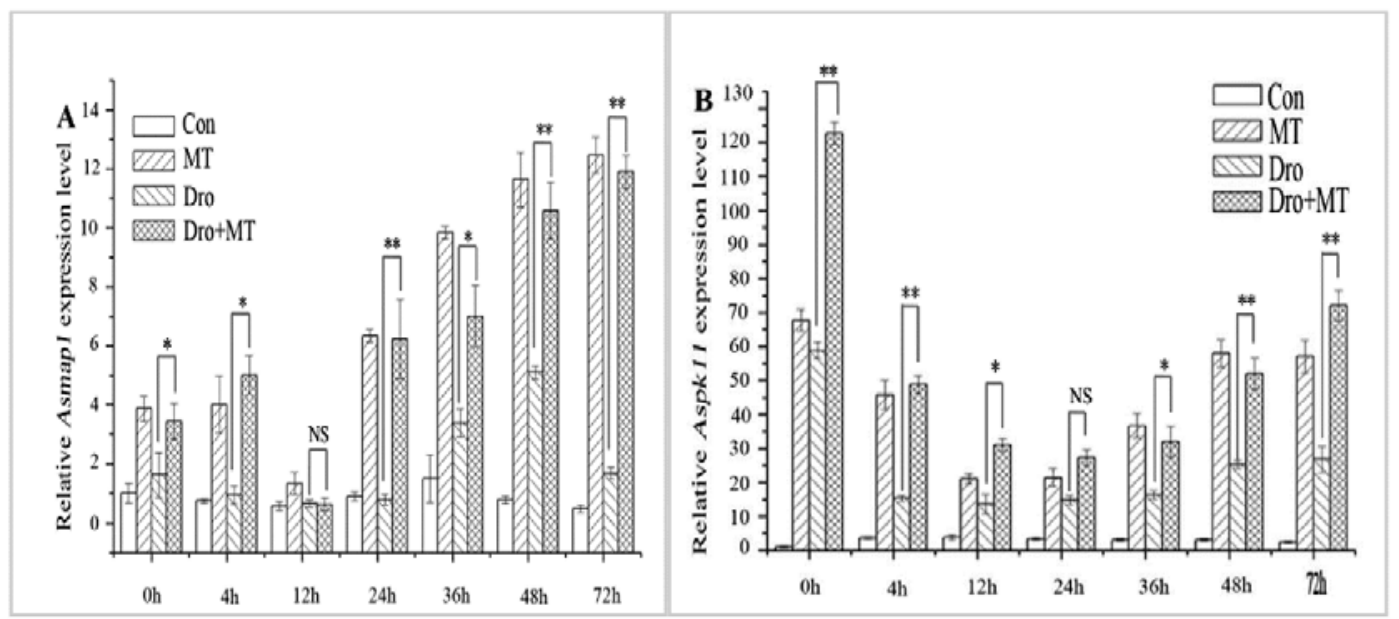

Figure 5. Effect of MT pretreatment on expression of MAPKs in leaves of naked oat seedlings. The relative expression of protein kinase genes Asmap1 (A) and Aspk11 (B). Values represent mean \pm standard deviation $(n=3)$. Significant difference between drought with pretreatment MT and drought-treated. Asterisks; ${ }^{*}, *$ indicate $p$ values, $<0.05$ and 0.01 , respectively. NS; No significance. Drought plus melatonin pretreatment at times $0,4,12,24,36,48$, and $72 \mathrm{~h}$.

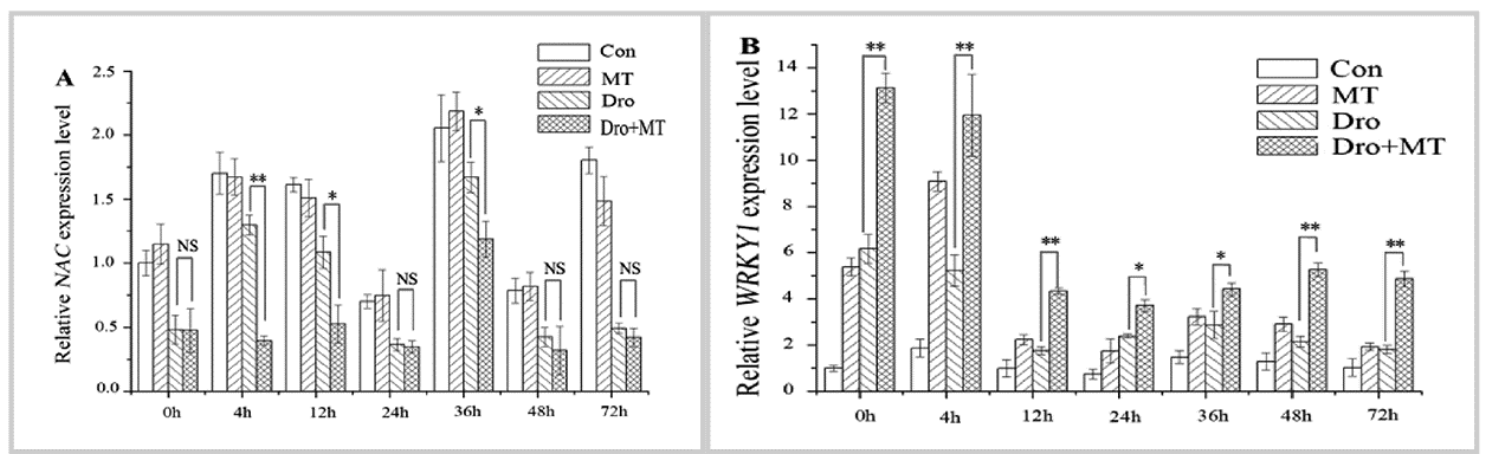

Figure 6. Cont. 


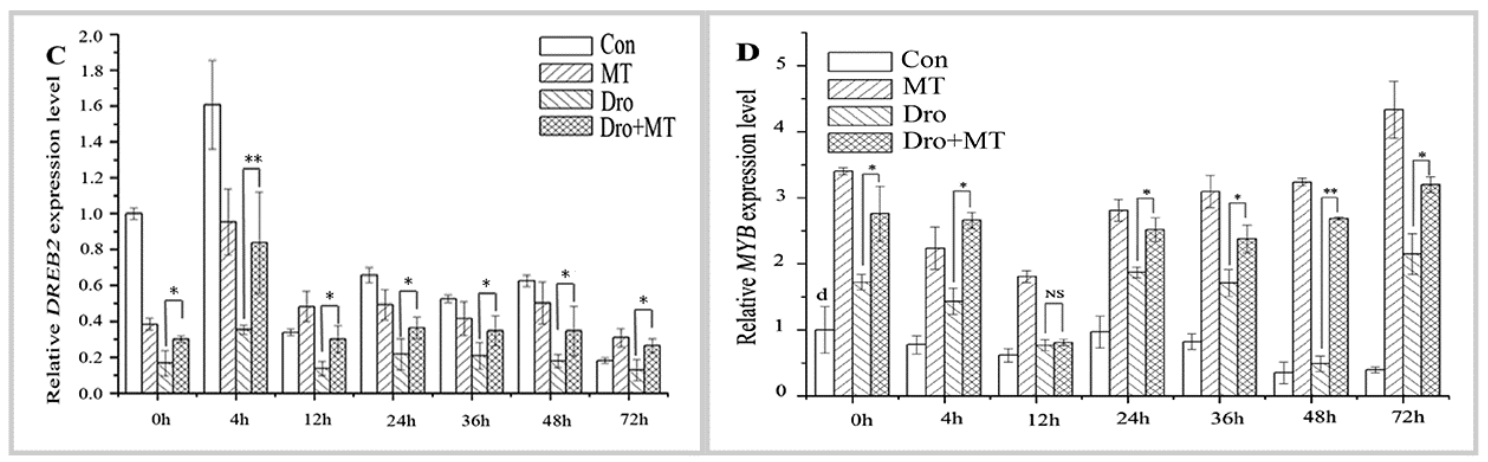

Figure 6. Effect of melatonin pretreatment on the expression of antioxidant-related TFs in leaves of naked oat seedlings. The relative expression of the related TFs genes NAC (A); WRKY1 (B); DREB2 $(\mathbf{C})$; and $M Y B(\mathbf{D})$. Values represent mean \pm standard deviation $(n=3)$. Significant difference between drought with pretreatment MT and drought-treated. Asterisks; ${ }^{*},{ }^{* *}$ indicate $p$ values, $<0.05$ and 0.01 , respectively. NS; No significance. Drought plus melatonin pretreatment at times $0,4,12,24,36$, 48, and $72 \mathrm{~h}$.

\section{Discussion}

MT is an indoleamine that acts like an auxin (indole acetic acid) in plants to promote the growth of vegetative organs such as roots and leaves [38] as well as promote seed germination and seedling growth $[39,40]$. In the present experiment, we soaked naked oat seeds in different concentrations of MT. The effect of MT on seed germination rate, germination index, germination potential, and germination survival rate of the naked oat as a whole was manifested as promotion at a low concentration, and inhibition at a high concentration (Figure S1). The seed germination rate of the naked oat seeds was inversely related to the MT concentration. This result agreed with earlier studies in pea [41], but was contrary to the seed germination results of the same MT concentrations in Arabidopsis thaliana [42]. The differences in seed germination between the naked oat and Arabidopsis thaliana may be due to the differences in environmental conditions at the time of germination. The condition of Arabidopsis thaliana seeds germination was drought plus MT treatment, while the naked oat was only treated with MT. Moreover, the antioxidant potential of different plant seeds during germination differed [43], resulting in differences in germination between the naked oat and Arabidopsis thaliana.

Drought stress inhibited the growth of naked oat seedlings, whereas the MT pretreatment alleviated the inhibition of naked oat seedling growth caused by drought stress (Figure 3). Similarly, promotion of seedling growth has also been observed in soybean [44] and Bermuda grass (Cynodon dactylon (L.) Pers.) [45] under drought and salt stress conditions, but differed in the MT pretreatment concentration. Therefore, the effects of MT on plant growth under drought stress may be related to different sensitivities to MT by different plant species.

The production and elimination of ROS are unbalanced in plant cells under drought stress, and a large amount of ROS are produced, causing oxidative damage to plants [46]. MT induces antioxidant enzyme activities [47], which help to maintain a balance of ROS. The activities of the antioxidant enzymes SOD, POD, CAT, and APX were higher in the naked oat under drought stress with the MT pretreatment, and the enzyme activities increased as drought stress duration was prolonged (Figure 3). Similar studies in grape [46] and rapeseed [33] have shown that MT also enhanced antioxidant enzyme activities, thereby improving resistance to stress. Simultaneously, the drought treatment resulted in increased $\mathrm{H}_{2} \mathrm{O}_{2}$ and $\mathrm{O}^{2-} \bullet$ contents in naked oat leaves, and the MT pretreatment reduced the contents of $\mathrm{H}_{2} \mathrm{O}_{2}$ and $\mathrm{O}^{2-} \bullet$ (Figure 4), effectively inhibiting the increase in ROS in leaves of naked oat seedlings under drought stress. These results were similar to the effect of MT on wheat [47] and rapeseed [33]. These results showed that MT induced the increase in antioxidant enzyme activities in naked oat leaves to remove excess ROS and protect against oxidative stress in the plants. 
The aerobic metabolites of cells are ROS. Stress increases the active oxygen yield and causes damage to cells. The $\mathrm{H}_{2} \mathrm{O}_{2}$ is an important signaling molecule for the plant stress response, and is widely involved in plant physiological and cross-resistance processes [8]. $\mathrm{H}_{2} \mathrm{O}_{2}$ acts as a second messenger in signal transduction of brassinosteroids (BRs) and abscisic acid (ABA)-induced plant resistance [48]. Xia et al. [48] speculated that BRs may induce the MAPK cascade reaction through the $\mathrm{H}_{2} \mathrm{O}_{2}$ pathway, thereby regulating the expression of antioxidant enzyme genes and promoting antioxidant enzyme activities, thereby enhancing the stress resistance of cucumber. In the present study, a large amount of $\mathrm{H}_{2} \mathrm{O}_{2}$ was produced under drought treatment in the leaves of the naked oat. $\mathrm{H}_{2} \mathrm{O}_{2}$ acted as a second messenger to activate the downstream MAPK cascade and upregulated the expression of antioxidant-related TFs genes, thereby enhancing naked oat seedling tolerance (Figures 4-6). MT has a similar mechanism to BRs. MT pretreatment enhanced antioxidant enzyme activity and upregulated the expression of MAPKs and TFs genes (Figures 3-6). This further confirmed the two effects of MT: MT scavenged ROS by enhancing antioxidant enzyme activity; (ii) MT might also induce MAPK cascade through the $\mathrm{H}_{2} \mathrm{O}_{2}$ pathway, thus improving the drought tolerance of naked oat seedlings. These results may provide new evidence to clarify the underlying mechanism of MT.

The MAPK cascade pathway responds to various biotic and abiotic stressors in plants, such as bacteria, high salinity, drought, and oxidative stress [49-51]. Phosphorylate MAPK acted as a bridge between upstream receptors and downstream transcription factor genes, and enhanced expression of the transcription factors NAC, WRKY1, DREB2, and MYB of naked oat. Activated TFs further regulated the expression of downstream responsive genes, thereby enhancing drought tolerance. In Arabidopsis, flagellin flg22 triggered the complete MAPK cascade and MEKK1-MKK4/5-MAPK3/6 activated the expression of the downstream gene WRKY22/29, which enhanced plant resistance to bacterial and fungal pathogens [52]. In rice, OsMAPK3 phosphorylates SP sites of OsWRKY30, enhancing tolerance to drought stress [53]. In the present study, Asmap1 and Aspk11 are two MAPKs in naked oat that were induced under drought with and without MT. The relative expression levels of Asmap1 and Aspk11, which were involved in regulating the MAPK cascade through the $\mathrm{H}_{2} \mathrm{O}_{2}$ pathway, were significantly $(p<0.05)$ upregulated in response to drought stress. However, their relative expression was higher in drought plus MT plants. Thus, MT likely induced the MAPK cascade through the $\mathrm{H}_{2} \mathrm{O}_{2}$ pathway, which further enhanced the drought tolerance of naked oat seedlings.

TFs regulate the expression of eukaryotic genes, especially when plants are exposed to stress, such as drought or high temperature. TFs regulate the expression of downstream resistance genes, enhancing the plant's resistance to stress [36]. The TFs that participate in plant stress resistance include NAC, WRKY, MYB, and DREB [37]. The rice NAC family (such as OsNAP, OsNAC22, SNAC1, and SNAC3) is induced by drought or ABA, which enhances drought resistance [54-56] and heat resistance [57] through the ABA pathway. The WRKY transcription factor family (LtWRKY21) in shrub plants enhances drought resistance though the ABA signal transduction pathways by enhancing the expression of downstream genes [58]. Overexpression of the WRKY transcription factor genes (OsWRKY45 and WRKY57) in Arabidopsis upregulates ABA levels and increases drought tolerance [59,60]. Thus, the mechanism of MT-induced drought tolerance in naked oat may also involve the ABA signaling pathway, which needs further study. Studies have confirmed that the overexpression of the OsWRKY 45 and WRKY57 genes is affected by ROS [61]. However, drought treatment decreased expression of the transcription factors GmNAC2 and GhWRKY17 in tobacco, but induces the production of ROS [62,63]. In the current study, after drought with and without MT pretreatment, the expression levels of WRKY1 and MYB were significantly $(p<0.05)$ upregulated (Figure $6 \mathrm{~B}, \mathrm{D})$, but there was no significant change in the expression level of NAC (Figure 6A). Compared with drought alone, the expression level of DREB2 was significantly $(p<0.05)$ upregulated (Figure $6 C$ ) in drought with MT-pretreatment. These results suggest that the TFs family NAC, WRKY1, DREB2, and MYB may be involved the MAPK cascade through the $\mathrm{H}_{2} \mathrm{O}_{2}$-induced signaling pathways in the stress response of naked oat. In summary, it is speculated that MT enhanced the drought stress response in naked oat seedlings (Figure 7). MT promoted the production and accumulation of ROS in cells. As the 
concentration of ROS in cells increased, MT acted as antioxidants to scavenge ROS and enhance antioxidant enzyme activities. The generated ROS induced or activated the downstream MAPKs and TFs, and regulated the expression of downstream resistance genes, which enhanced drought tolerance. Thus, appropriate concentrations of MT could positively stimulate stress resistance in naked oat, but further study is required to fully understand the response mechanism and signaling pathways of MT under drought stress in naked oat.

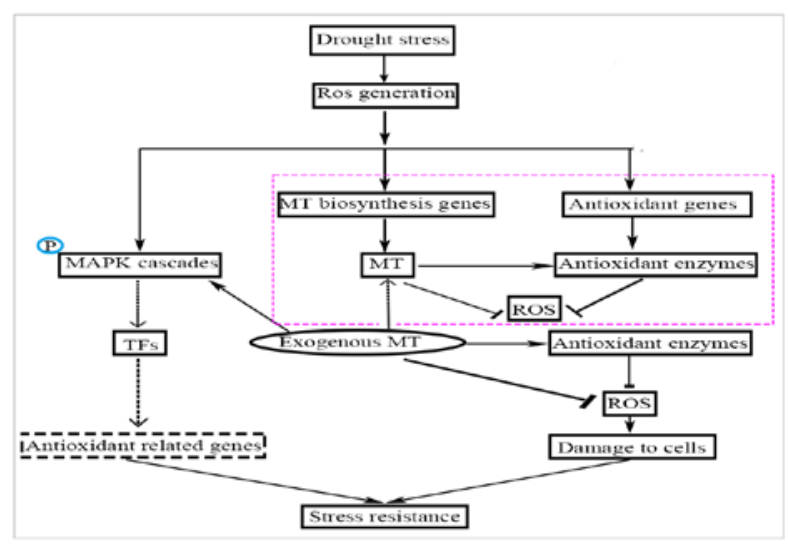

Figure 7. A schematic plot showing the potential mechanism of melatonin-mediated alleviation of drought-induced oxidative stress in naked oat seedlings [36,64].

\section{Materials and Methods}

\subsection{Plant Materials}

Naked oat seeds of the 'Jin Yan No. 2' cultivar (A. nuda L.) were provided by the Provincial Key Laboratory of Biotechnology of Shaanxi Province, Northwest University, Xi'an 710069, Shaanxi Province, China. They were stored at $4{ }^{\circ} \mathrm{C}$ under dry conditions, before the experiments started.

\subsection{Seed Germination Conditions}

Naked oat seeds were surface-sterilized with a 75\% $(v / v)$ alcohol solution for $15 \mathrm{~s}$, washed two to three times in distilled water, sterilized with $1 \% \mathrm{HgCl}_{2}(\mathrm{~m} / \mathrm{v})$ for $7 \mathrm{~min}$, and washed again five or six times in distilled water. The seeds were soaked in a $100 \mu \mathrm{M}$ concentration for $12 \mathrm{~h}$, then placed on 14-cm diameter Petri dishes (40 seeds per dish) with three layers of filter paper in a dark growth chamber $\left(23-25^{\circ} \mathrm{C} / 16-18{ }^{\circ} \mathrm{C}\right.$ day/night) for germination. All seeds were fertilized daily with half-strength Hoagland solution $(\mathrm{pH} 6.5 \pm 0.1)$. On the basis of the state of naked oat germination and growth in our preliminary studies, we selected a concentration of $100 \mu$ M MT (Figure S1).

\subsection{MT Pretreatment}

After the emergence of the radicle, seedlings were shifted to hydroponic conditions containing half-strength Hoagland solution. After five days, half of the seedlings were shifted to half-strength Hoagland solution, while the other half was shifted to half-strength Hoagland solution containing $100 \mu \mathrm{M}$ MT. A total of $0.05807 \mathrm{~g}$ of MT was dissolved in ethanol absolute at a concentration of Twenty-five $\mathrm{mmol} / \mathrm{L}$ and stored at $-20{ }^{\circ} \mathrm{C}$. Twenty-five mmol/L of MT was further diluted to $100 \mu \mathrm{M}$. The naked oat leaves were sprayed with $100 \mu \mathrm{M}$ of MT for the first time at 8 p.m. and then sprayed once every day. Exogenous $100 \mu \mathrm{M}$ MT was sprayed three times and the experimental period was six days. During the MT pretreatment, seedlings were selected and placed in a growth room with a relative humidity of $75 \%$, a $14 \mathrm{~L}: 10 \mathrm{D}$ photoperiod, and day/night temperatures of $(25 \pm 1)^{\circ} \mathrm{C} /(17 \pm 1)^{\circ} \mathrm{C}$. 


\subsection{Drought-Stress Treatment}

After two days of MT pretreatment, a 20\% ( $\mathrm{m} / \mathrm{v})$ poly-ethylene glycol-6000 (PEG-6000) drought stress treatment was applied. Naked oat leaves were harvested at $0,4,12,24,36,48$, and $72 \mathrm{~h}$ after the drought stress treatment, rapidly frozen in liquid nitrogen, and stored at $-80^{\circ} \mathrm{C}$ for further analysis. The experiment was divided into four groups of experiments with 60 seedlings each. According to the growth states of naked oat seedlings under different drought stress conditions, and the effect of spraying different concentrations of MT on the leaves of naked oat seedlings under 20\% PEG-6000 drought stress (Figures S2-S4), the concentration of MT (100 $\mu \mathrm{M})$ and PEG-6000 (20\%) was selected based on our results.

\subsection{Determination of Various Indicators}

\subsubsection{Calculation of Plant Height, Stem Thickness, Plant Fresh Weight, and Plant Dry Weight}

After treatment in 20\% PEG-6000 for three days, seedlings were randomly selected from each dish and plant height, stem thickness, plant fresh weight, and plant dry weight were measured. The height of the plant was the length of the seedling, which was the linear distance from the base of the radicle to the top of the blade. The fresh/dry weight of the seedling was the total fresh/dry weight of the entire seedling. Naked oat seedlings were harvested, then washed with tap water and rinsed three times with distilled water, gently wiped dry with a paper towel and their fresh weight (FW) was determined rapidly. Then, the seedlings were dried at $105^{\circ} \mathrm{C}$ for $30 \mathrm{~min}$, and dried at $80^{\circ} \mathrm{C}$ for $24 \mathrm{~h}$ to measure their dry weight (DW). Three parallel experiments were performed simultaneously.

\subsubsection{Enzyme Extraction and Assay}

All enzymes were extracted by grinding $0.2 \mathrm{~g}$ of fresh leaves with $3 \mathrm{~mL}$ of ice-cold $50 \mathrm{mM}$ phosphate buffer ( $\mathrm{pH}$ 7.8) containing liquid nitrogen using a chilled mortar and pestle. The homogenate was centrifuged at $11,000 \mathrm{rpm} / \mathrm{min}$ for $20 \mathrm{~min}$ at $4{ }^{\circ} \mathrm{C}$, and the supernatant was used for the specific enzyme activity assays. The activity of SOD (EC 1.15.1.1) was determined by the method described by Giannopolitis and Ries. [65] through measuring its ability to inhibit the photochemical reduction of nitro blue tetrazolium (NBT) in a spectrophotometer at $560 \mathrm{~nm}$, the POD (EC 1.11.1.7) activity analysis was calculated using guaiacol in a spectrophotometer at $470 \mathrm{~nm}$ according to the method described by Cakmak and Marschner [66], CAT (EC 1.11.1.6) activity was assessed in spectrophotometer at $240 \mathrm{~nm}$ according to Hamurcu et al. [67], and APX (EC 1.11.1.11) activity was measured in a spectrophotometer at $290 \mathrm{~nm}$ by the method described by Nakano and Asada [68].

\subsubsection{Determination of $\mathrm{H}_{2} \mathrm{O}_{2}$ and $\mathrm{O}^{2-} \bullet$}

Production of $\mathrm{H}_{2} \mathrm{O}_{2}$ was estimated following $\mathrm{Yu}$ et al. [69]. Naked oat leaves were extracted by grinding $0.2 \mathrm{~g}$ of fresh leaves with $3 \mathrm{~mL}$ of ice-cold $50 \mathrm{mM}$ phosphate buffer ( $\mathrm{pH}$ 6.5) containing liquid nitrogen using a chilled mortar and pestle. The homogenate was centrifuged at 11,500 rpm/min for $10 \mathrm{~min}$ at $25^{\circ} \mathrm{C}$, and the supernatant was used for the $\mathrm{H}_{2} \mathrm{O}_{2}$ content assay in a spectrophotometer at $410 \mathrm{~nm}$.

$\mathrm{O}^{2-} \bullet-$ was measured through a method described by Velikova et al. [70]. Leaves were extracted by grinding $0.3 \mathrm{~g}$ of fresh leaves with $3 \mathrm{~mL}$ of ice-cold $50 \mathrm{mM}$ potassium phosphate buffer ( $\mathrm{pH} 7.8$ ) containing liquid nitrogen using a chilled mortar and pestle. The homogenate was centrifuged at $5000 \mathrm{rpm} / \mathrm{min}$ for $20 \mathrm{~min}$ at $25^{\circ} \mathrm{C}$, and the supernatant was used for the $\mathrm{O}^{2-} \bullet$ content assay in a spectrophotometer at $530 \mathrm{~nm}$.

\subsubsection{Quantitate Real Time-Polymerase Chain Reaction (qRT-PCR) Analysis}

The drought-tolerant related gene sequences of oat Asmap1 (X79993.1), Aspk11 (X79992.1), NAC (KU886332.1), WRKY1 (AF140554.1), DREB2 (EF672101.1), and MYB (AJ133638.1) were searched on 
NCBI; they were compared with the gene sequences of other species by BLAST, and the homologous sequences of the genes from several species were downloaded. Degenerate primers were designed and the conserved regions sequences were amplified ( $\leq 800 \mathrm{bp}$ ) and verified using MEGA software (Center for Evolutionary Medicine and Informatics, The Biodesign Institute, McAllister Ave, Tempe, AZ, USA). The qRT-PCR primers were designed using Primer 5.0 software (Premier Biosoft, Palo Alto, CA, USA) (Table 1).

Table 1. Drought-tolerance relative genes and primers used in real-time qPCR analysis.

\begin{tabular}{ccc}
\hline Gene Name & Sense Primer & Anti-Sense Primer \\
\hline NAC & GGAGTCGGAGATCGTGGACACC & TGGATGTCGTCGTAGCTGAGGTC \\
DREB2 & ATACCGTGGTGTGAGGCAG & CGAGATACGAGAAGGAGGA \\
WRKY1 & GGCGTCCTCCTTCCTCCAGTC & CCTCGTATGGCGTGCTGAAGC \\
MYB & GAACCAGCAGCCGTCTGTGAG & GCAGGAGCGGTGGATTCAGTG \\
Asmap1 & CATCCGCTCCAACCAAGAACTCTC & TACTCCGTCATCATGTCGCTCTCC \\
Aspk11 & GGTCCATACCCCCACAGA & TAGTCCAACAGCCTCATT \\
Actin & ATGTTGCCATCCAGGCTGTG & TAAGTCACGTCCAGCGAGGT \\
\hline
\end{tabular}

The TRIzol reagent (Invitrogen, Carlsbad, CA, USA) method was used to extract total RNA from naked oat leaves. First-strand cDNA was synthesized using the PrimeScriptTM RT reagent kit with the gDNA Eraser (Takara, Shiga, Japan) according to the manufacturer's instructions. qRT-PCR was performed on a Bio-Rad CFX96 Real-Time PCR System (Bio-Rad, Hercules, CA, USA) using FastStart Essential DNA Green Master (Tiangen, Beijing, China). The procedure was as follows: $95^{\circ} \mathrm{C}$ for $10 \mathrm{~min}$, one cycle, 40 cycles of $95^{\circ} \mathrm{C}$ for $10 \mathrm{~s}$, and $60^{\circ} \mathrm{C}$ for $30 \mathrm{~s}$. Finally, the melting curves were performed to confirm the specificity of the primers again by heating up the products from $60^{\circ} \mathrm{C}$ to $95^{\circ} \mathrm{C}$. The Actin (KP257585.1) housekeeping gene was used to normalize the relative expression levels of the candidate genes. Three independent biological replications were performed for each experiment. The relative gene expression levels were calculated according to the $2^{-\Delta \Delta C t}$ method and presented as fold changes.

\subsection{Statistical Analysis}

The experiments were divided into the control untreated group (Con), melatonin-treated (MT), drought-treated group (Dro), and drought-treated group with melatonin (Dro + MT). All experiments were repeated three times, and mean values were presented with standard deviations. One-way analysis of variance (ANOVA) was according to Duncan's test by SPSS 20.0 (IBM, Armonk, NY, USA). The difference was considered to be statistically significant when $p<0.05$. Student's $t$-test was also used to analyze the significant differences between drought with pretreatment MT. Data were plotted using Origin8.0 (OriginLab, Hampton, MA, USA) and graphs were edited in Photoshop CS5 (Adobe, USA).

Supplementary Materials: The following are available online, Figure S1: Effect of different MT concentrations on germination of naked oat seeds, Figure S2: Effect of spraying different concentrations of MT on the growth of naked oat seedlings, Figure S3: Effect of different concentrations of drought treatment on the growth of naked oat seedlings, Figure S4: Effect of spraying different concentrations of MT treatment on the growth of naked oat seedlings under 20\% PEG-6000 drought stress.

Author Contributions: Y.W. designed the studies and revised the paper; W.G. and Y.Z. performed the experiments and edited the graphs; Z.F. and Q.B. analyzed and discussed data; W.G. and J.H. wrote the paper. All the authors read and approved the final manuscript.

Acknowledgments: This study was supported by the Shannxi Provincial Department of Education Research Project (Key Laboratory Project) (2018 J S-172) and the National Natural Science Foundation of China (31572665).

Conflicts of Interest: The authors declare no conflicts of interest. 


\section{Abbreviations}

$\begin{array}{ll}\mathrm{MT} & \text { Melatonin } \\ \mathrm{H}_{2} \mathrm{O}_{2} & \text { Hydrogen peroxide } \\ \mathrm{O}^{2-} \bullet & \text { Superoxide anion } \\ \text { SOD } & \text { Superoxide dismutase } \\ \text { POD } & \text { Peroxidase } \\ \text { CAT } & \text { Catalase } \\ \text { APX } & \text { Ascorbate peroxidase } \\ \text { PEG-6000 } & \text { Poly-ethylene glycol-6000 } \\ \text { MAPKs } & \text { Mitogen-activated protein kinases } \\ \text { TF } & \text { Transcription factor } \\ \text { ROS } & \text { Reactive oxygen species } \\ \text { ABA } & \text { Abscisic acid } \\ \text { BRs } & \text { Brassinosteroids }\end{array}$

\section{References}

1. Wang, T.; Du, Y.L.; He, J.; Turner, N.C.; Wang, B.R.; Zhang, C.; Cui, T.; Li, F.M. Recently-released genotypes of naked oat (Avena nuda L.) out-yield early releases under water-limited conditions by greater reproductive allocation and desiccation tolerance. Field Crops Res. 2017, 204, 169-179. [CrossRef]

2. Song, G.Y.; Huo, P.J.; Wu, B.; Zhang, Z.W. A genetic linkage map of hexaploid naked oat constructed with SSR markers. Crop J. 2015, 3, 353-357. [CrossRef]

3. Lin, W.J.; Wu, G.F.; Li, C.H.; Wang, Y.; Zhou, S.M. Effects of cultivar and environment on nutritional quality of Chinese naked oats. Acta Agron. Sin. 2011, 37, 1087-1092. [CrossRef]

4. Marta, B.; Katarzyna, S.; Malgorzata, M.P. Exogenous Melatonin Improves Antioxidant Defense in Cucumber Seeds (Cucumis Sativus L.) Germinated under Chilling Stress. Front. Plant Sci. 2016, 7, 575. [CrossRef] [PubMed]

5. Qi, J.S.; Song, C.P.; Wang, B.S.; Zhou, J.M.; Kangasjärvi, J.; Zhu, J.K.; Gong, Z.Z. ROS signaling and stomatalmovement in plant responses to drought stress and pathogen attack. J. Integr. Plant Biol. 2018, 1-53. [CrossRef]

6. Farooq, M.; Wahid, A.; Kobayashi, N.; Fujita, D.; Basra, S. Plant drought stress: Effects, mechanisms and management. Agron. Sustain. Dev. 2009, 29, 185-212. [CrossRef]

7. Nahar, K.; Hasanuzaman, M.; Alam, M.M.; Fujita, M. Roles of exogenous glutathione in antioxidant defense system and methylglyoxal detoxification during salt stress in mung bean. Biol. Plant. 2015, 59, 745-756. [CrossRef]

8. Apel, K.; Hirt, H. Reactive oxygen species: Metabolism, oxidative stress, and signal transduction. Annu. Rev. Plant Biol. 2004, 55, 373-379. [CrossRef] [PubMed]

9. Gechev, T.S.; Van Breusegem, F.; Stone, J.M.; Denev, I.; Laloi, C. Reactive oxygen species as signals that modulate plant stress responses and programmed cell death. Bioessays 2006, 28, 1091-1101. [CrossRef] [PubMed]

10. Wang, M.; Li, Q.R.; Fu, S.L.; Dong, B.L. Effects of exogenous nitric oxide on photosynthetic characteristics of poplar leaves under water stress. Chin. J. Appl. Ecol. 2005, 16, 218-222.

11. Hardeand, R.; Madrid, J.A.; Tan, D.X.; Reiter, R.J. Melatonin, the circadian multioscillator system and health: The need for detailed analyses of peripheral melatonin signaling. J. Pineal Res. 2012, 34, $233-241$.

12. Calvo, J.R.; Gonzalez Yanes, C.; Maldonado, M.D. The role of melatonin in the cells of the innate immunity: A review. J. Pineal Res. 2013, 55, 103-120. [CrossRef] [PubMed]

13. Orendáš, P.; Kubatka, P.; Bojková, B.; Kassayová, M.; Kajo, K.; Výbohová, D.; Kružliak, P.; Péč, M.; Adamkov, M.; Kapinová, A.; et al. Melatonin potentiates the anti-tumour effect of pravastatin in rat mammary gland carcinoma model. Int. J. Exp. Pathol. 2014, 95, 401-410. [CrossRef] [PubMed]

14. Kubatka, P.; Kalická, K.; Chamilová, M.; Ahlersová, E.; Ahlers, I.; Bojková, B.; Adámeková, E. Nimesulide and melatonin in mammary carcinogenesis prevention in female Sprague Dawley rats. Neoplasma 2002, 49, 255-259. [PubMed] 
15. Galano, A.; Tan, D.X.; Reiter, R.J. On the free radical scavenging activities of melatonin's metabolites, AFMK and AMK. J. Pineal Res. 2012, 54, 245-257. [CrossRef] [PubMed]

16. Karaaslan, C.; Suzen, S. Antioxidant properties of melatonin and its potential action in diseases. Curr. Top . Med. Chem. 2015, 15, 894-903. [CrossRef] [PubMed]

17. Suwanjang, W.; Abramov, A.Y.; Charngkaew, K.; Govitrapong, P.; Chetsawang, B. Melatonin prevents cytosolic calcium overload, mitochondrial damage and cell death due to toxically high doses of dexamethasone-induced oxidative stress in human neuroblastoma SH-SY5Y cells. Neurochem. Int. 2016, 97, 34-41. [CrossRef] [PubMed]

18. Dubbels, R.; Reiter, R.J.; Klenke, E.; Goebel, A.; Schnakenberg, E.; Ehlers, C.; Schiwara, H.W.; Schloot, W. Melatonin in edible plants identified by radioimmunoassay and by high performance liquid chromatographymass spectrometry. J. Pineal Res. 1995, 18, 28-31. [CrossRef] [PubMed]

19. Hattori, A.; Migitaka, H.; Iigo, M.; Itoh, M.; Yamamoto, K.; Ohtani Kaneko, R.; Hara, M.; Suzuki, T.; Reiter, R.J. Identificaton of melatonin in plants and its effects on plasma melatonin levels and binding to melatonin receptors in vertebrates. Biochem. Mol. Biol. Int. 1995, 35, 627-634. [PubMed]

20. Manchester, L.C.; Tan, D.X.; Reiter, R.J.; Park, W.; Monis, K.; Qi, W. High levels of melatonin in the seeds of edible plants: Possible function in germ tissue protection. Life Sci. 2000, 67, 3023-3029. [CrossRef]

21. Ramakrishna, A.; Giridhar, P.; Sankar, K.U.; Ravishankar, G.A. Melatonin and serotonin profiles in beans of Coffea species. J. Pineal Res. 2012, 52, 470-476. [CrossRef] [PubMed]

22. Arnao, M.B.; Hernández Ruiz, J. Growth conditions influence the melatonin content of tomato plants. Food Chem. 2013, 138, 1212-1214. [CrossRef] [PubMed]

23. Vitalini, S.; Gardana, C.; Simonetti, P.; Fico, G.; Iriti, M. Melatonin, melatonin isomers and stilbenes in Italian traditional grape products and their antiradical capacity. J. Pineal Res. 2013, 54, 322-333. [CrossRef] [PubMed]

24. Zhang, N.; Zhang, H.J.; Zhao, B.; Sun, Q.Q.; Cao, Y.Y.; Li, R.; Wu, X.X.; Weeda, S.; Li, L.; Ren, S.; et al. The RNA-seq approach to discriminate gene expression profiles in response to melatonin on cucumber lateral root formation. J. Pineal Res. 2014, 56, 39-50. [CrossRef] [PubMed]

25. Arnao, M.B.; Hernández-Ruiz, J. Protective effect of melatonin against chlorophyll degradation during the senescence of barley leaves. J. Pineal Res. 2009, 46, 58-63. [CrossRef] [PubMed]

26. Tan, D.X.; Hardeland, R.; Manchester, L.C.; Korkmaz, A.; Ma, S.; Rosales Corral, S.; Reiter, R.J. Functional roles of melatonin in plants, and perspectives in nutritional and agricultural science. J. Exp. Bot. 2012, 63, 577-597. [CrossRef] [PubMed]

27. Byeon, Y.; Park, S.; Kim, Y.S.; Park, D.H.; Lee, S.; Back, K. Light regulated melatonin biosynthesis in rice during the senescence process in detached leaves. J. Pineal Res. 2012, 53, 107-111. [CrossRef] [PubMed]

28. Wang, P.; Sun, X.; Li, C.; Wei, Z.; Liang, D.; Ma, F. Long-term exogenous application of melatonin delays drought-induced leaf senescence in apple. J. Pineal Res. 2013, 54, 292-302. [CrossRef] [PubMed]

29. Wang, P.; Yin, L.; Liang, D.; Li, C.; Ma, F.; Yue, Z. Delayed senescence of apple leaves by exogenous melatonin treatment: Toward regulating the ascorbate-glutathione cycle. J. Pineal Res. 2012, 53, 11-20. [CrossRef] [PubMed]

30. Park, S.; Lee, D.E.; Jang, H.; Byeon, Y.; Kim, Y.S.; Back, K. Melatonin-rich transgenic rice plants exhibit resistance to herbicide-induced oxidative stress. J. Pineal Res. 2013, 54, 258-263. [CrossRef] [PubMed]

31. Yin, L.; Wang, P.; Li, M.; Ke, X.; Li, C.; Liang, D.; Wu, S.; Ma, X.; Zou, Y.; Ma, F. Exogenous melatonin improves malus resistance to Marssonina apple blotch. J. Pineal Res. 2013, 54, 426-434. [CrossRef] [PubMed]

32. Meng, J.F.; Xu, T.F.; Wang, Z.Z.; Fang, Y.L.; Xi, Z.M.; Zhang, Z.W. The ameliorative effects of exogenous melatonin on grape cuttings under water-deficient stress: Antioxidant metabolites, leaf anatomy, and chloroplast morphology. J. Pineal Res. 2014, 57, 200-212. [CrossRef] [PubMed]

33. Li, J.J.; Zeng, L.; Cheng, Y.; Lu, G.Y.; Fu, G.P.; Ma, H.Q.; Liu, Q.Y.; Zhang, X.K. Exogenous melatonin alleviates damage from drought stress in rapeseed (Brassica napus L.) seedlings. Acta Physiol. Plant. 2018, 40. [CrossRef]

34. Chen, Y.E.; Cui, J.M.; Li, G.X.; Yuan, M.; Zhang, Z.W.; Yuan, S.; Zhang, H.Y. Effect of salicylic acid on the antioxidant system and photosystem II in wheat seedlings. Biol. Plant. 2016, 60, 139-147. [CrossRef]

35. Rodriguez, M.C.; Petersen, M.; Mundy, J. Mitogen-activated protein kinase signaling in plants. Annu. Rev. Plant Biol. 2010, 61, 621-649. [PubMed]

36. Xuan, L.T.H.; Du, N.H.N.; Nguyen, B.A.T.; Nguyen, P.T.; Lamson, P.T. Transcription factors and their roles in signal transduction in plants under abiotic stresses. Curr. Genom. 2017, 18, 483-497. 
37. Wang, J.; Zhang, L.; Cao, Y.; Qi, C.; Li, S.; Liu, L.; Wang, G.; Mao, A.; Ren, S.; Guo, Y.D. CsATAF1 positively regulates drought stress tolerance by ABA-dependent pathway and promoting ROS scavenging in cucumber. Plant Cell Physiol. 2018, 59, 930-945. [CrossRef] [PubMed]

38. Chen, Q.; Qi, W.B.; Reiter, R.J.; Wei, W.; Wang, B.M. Exogenously applied melatonin stimulates root growth and raises endogenous indoleacetic acid in roots of etiolated seedlings of Brassica juncea. J. Plant Physiol. 2009, 166, 324-328. [CrossRef] [PubMed]

39. Posmyk, M.M.; Balabusta, M.; Wieczorek, M.; Sliwinska, E.; Janas, K.M. Melatonin applied to cucumber (Cucumis sativus L.) seeds improves germination during chilling stress. J. Pineal Res. 2009, 46, 214-223. [CrossRef] [PubMed]

40. Arora, D.; Bhatla, S.C.; Janas, K.M. Melatonin and nitric oxide regulate sunflower seedling growth under salt stress accompanying differential expression of $\mathrm{Cu} / \mathrm{Zn}$ SOD and MnSOD. Free Radic. Biol. Med. 2017, 106, 315-328. [CrossRef] [PubMed]

41. Tan, D.X.; Manchester, L.C.; Helton, P.; Reiter, R.J. Phytoremediative capacity of enriched with melatonin. Plant Signal Behav. 2007, 2, 514-516. [CrossRef] [PubMed]

42. Hernández, I.G.; Gomez, F.J.; Cerutti, S.; Arana, M.V.; Silva, M.F. Melatonin in Arabidopsis thaliana acts as plant growth regulator at low concentrations and preserves seed viability at high concentrations. Plant Physiol. Biochem. 2015, 94, 191-196. [CrossRef] [PubMed]

43. Poeggeler, B.; Thuermann, S.; Dose, A.; Schoenke, M.; Burkhardt, S.; Hardeland, R. Melatonin's uniue radical scavenging properties-roles of its functional substituents as revealed by a comparison with its structural analogs. J. Pineal Res. 2002, 33, 20-30. [CrossRef] [PubMed]

44. Wei, W.; Li, Q.T.; Chu, Y.N.; Reiter, R.J.; Yu, X.M.; Zhu, D.H.; Zhang, W.K.; Ma, B.; Lin, Q.; Zhang, J.S.; et al. Melatonin enhances plant growth and abiotic stress tolerance in soybean plants. J. Exp. Bot. 2014, 66, 695-707. [CrossRef] [PubMed]

45. Shi, H.; Jiang, C.; Ye, T.; Tan, D.X.; Reiter, R.J.; Zhang, H.; Liu, R.; Chan, Z. Comparative physiological, metabolomic, and transcriptomic analyses reveal mechanisms of improved abiotic stress resistance in bermudagrass [Cynodon dactylon (L.) Pers.] by exogenous melatonin. J. Exp. Bot. 2014, 66, 681-694. [CrossRef] [PubMed]

46. Gill, S.S.; Tuteja, N. Reactive oxygen species and antioxidant machinery in abiotic stress tolerance in crop plants. Plant Physiol. Biochem. 2010, 48, 909-930. [CrossRef] [PubMed]

47. Cui, G.B.; Zhao, X.; Liu, S.; Sun, F.; Zhang, C.; Xi, Y. Beneficial effects of melatonin in overcoming drought stress in wheat seedlings. Plant Physiol. Biochem. 2017, 118, 138-149. [CrossRef] [PubMed]

48. Xia, X.J.; Wang, Y.J.; Zhou, Y.H.; Tao, Y.; Mao, W.H.; Shi, K.; Asami, T.; Chen, Z.X.; Yu, J.Q. Reactive oxygen species are involved in brassinosteroids-induced stress tolerance in cucumber. Plant Physiol. 2009, 150, 801-814. [CrossRef] [PubMed]

49. Zhang, L.; Xi, D.; Luo, L.; Meng, F.; Li, Y.; Wu, C.A.; Guo, X. Cotton GhMPK2 is involved in multiple signaling pathways and mediates defense responses to pathogen infection and oxidative stress. FEBS J. 2011, 278, 1367-1378. [CrossRef] [PubMed]

50. Zhang, D.; Jiang, S.; Pan, J.; Kong, X.; Zhou, Y.; Liu, Y.; Li, D. The overexpresssion of a maize mitogen-activated protein kinase gene (ZmMPK5) confers salt stress tolerance and induces defence responses in tobacco. Plant Biol. 2014, 16, 558-570. [CrossRef] [PubMed]

51. Zhang, L.; Xi, D.; Li, S.; Li, S.; Gao, Z.; Zhao, S.; Shi, J.; Wu, C.; Guo, X. A cotton group C MAP kinase gene, GhMPK2, positively regulates salt and drought tolerance in tobacco. Plant Mol. Biol. 2011, 77, 17-31. [CrossRef] [PubMed]

52. Asai, T.; Tena, G.; Plotnikova, J.; Willmann, M.R.; Chiu, W.L.; Gomez Gomez, L.; Boller, T.; Ausubel, F.M.; Sheen, J. MAP kinase signalling cascade in Arabidopsis innate immunity. Nature 2002, 415, 977-983. [CrossRef] [PubMed]

53. Danquah, A.; Zelicourt, A.D.; Colcombet, J.; Hirt, H. The role of ABA and MAPK signaling pathway in plant abiotic stress responses. Biotechnol. Adv. 2014, 32, 40-52. [CrossRef] [PubMed]

54. Chen, X.; Wang, Y.; Lv, B.; Li, J.; Luo, L.; Lu, S.; Zhang, X.; Ma, H.; Ming, F. The NAC Family Transcription Factor OsNAP Confers Abiotic Stress Response Through the ABA Pathway. Plant Cell Physiol. 2014, 55, 604-619. [CrossRef] [PubMed] 
55. Hong, Y.; Zhang, H.; Huang, L.; Li, D.; Song, F. Overexpressing of a Stress-Responsive NAC Transcription Factor Gene ONAC022 Improves Drought and Salt Tolerance in rice. Front. Plant Sci. 2016, 7, 4. [CrossRef] [PubMed]

56. Hu, H.; Dai, M.; Yao, J.; Xiao, B.; Li, X.; Zhang, Q.; Xiong, L. Overexpressing a NAM, ATAF, and CUC(NAC) transcription factor enhances drought resistance and salt resistance in rice. Proc. Natl. Acad. Sci. USA 2006, 103, 12987-12992. [CrossRef] [PubMed]

57. Fang, Y.; Liao, K.; Du, H.; Xu, Y.; Song, H.; Li, X.; Xiong, L. A stress-responsive NAC transcription factor SNAC3 confers heat and drought tolerance through modulation of reactive oxygen species in rice. J. Exp. Bot. 2015, 66, 6803-6817. [CrossRef] [PubMed]

58. Zou, X.; Seemann, J.R.; Neuman, D.; Shen, Q.J. A WRKY gene from creosote bush encodes an activator of the abscisic acid signaling pathway. J. Biol. Chem. 2004, 279, 55770-55779. [CrossRef] [PubMed]

59. Qiu, Y.P.; Yu, D.Q. Over-expression of the stress-induced OsWRKY45 enhances disease resistance and drought tolerance in Arabidopsis. Environ. Exp. Bot. 2008, 65, 35-47. [CrossRef]

60. Jiang, Y.; Liang, G.; Yu, D. Activated expression of WRKY57 confers drought tolerance in Arabidopsis. Mol. Plant. 2012, 5, 1375-1388. [CrossRef] [PubMed]

61. Gadjev, I.; Vanderauwera, S.; Gechev, T.S.; Laloi, C.; Minkov, I.N.; Shulaev, V.; Apel, K.; Inzé, D.; Mittler, R.; Van Breusegem, F. Transcriptomic footprints disclose specificity of reactive oxygen species signaling in Arabidopsis. Plant Physiol. 2006, 141, 436-445. [CrossRef] [PubMed]

62. Jin, H.X.; Huang, F.; Cheng, H.; Song, H.N.; Yu, D.Y. Overexpression of the GmNAC2 Gene, an NAC transcriptional factor, reduces aAbiotic stress tolerance in tobacco. Plant Mol. Biol. Rep. 2013, 31, 435-442. [CrossRef]

63. Yan, H.; Jia, H.; Chen, X.; Hao, L.; An, H.; Guo, X. The cotton WRKY transcription factor GhWRKY17 functions in drought and salt stress in transgenic Nicotiana benthamiana through ABA signaling and the modulation of reactive oxygen species production. Plant Cell Physiol. 2014, 55, 2060-2076. [CrossRef] [PubMed]

64. Nawaz, M.A.; Jiao, Y.; Chen, C.; Shireen, F.; Zheng, Z.; Imtia, M.; Bie, Z.; Huang, Y. Melatonin pretreatment improves vanadium stress tolerance of watermelon on seedlings by reducing vanadium concentration in the leaves and regulating melatonin biosynthesis and antioxidant-related gene expression. J. Plant Physiol. 2018, 220, 115-127. [CrossRef] [PubMed]

65. Giannopolitis, C.N.; Ries, S.K. Superoxide dismutases: I. Occurence in higher plants. Plant Physiol. 1977, 54, 309-314. [CrossRef]

66. Cakmak, I.; Marschner, H. Magnesium deficiency and high light intensity enhance activities of superoxide dismutase, ascorbate peroxidase, and glutathione reductase in bean leaves. Plant Physiol. 1992, 98, 1222-1227. [CrossRef] [PubMed]

67. Hamurcu, M.; Sekmen, A.H.; Turkan, İ.; Gezgin, S.; Demiral, T.; Bell, R.W. Induced anti-oxidant activity in soybean alleviates oxidative stress under moderate boron toxicity. Plant Growth Regul. 2013, 70, 217-226. [CrossRef]

68. Nakano, Y.; Asada, K. Hydrogen peroxide is scavenged by ascorbate specific peroxidase in spinach chloroplast. Plant Cell Physiol. 1981, 22, 867-880.

69. Yu, C.W.; Murphy, T.M.; Lin, C.H. Hydrogen peroxideinduces chilling tolerance in mung beans mediated through ABA-independent glutathione accumulation. Funct. Plant Biol. 2003, 30, 955-963. [CrossRef]

70. Velikova, V.; Yordanov, I.; Edreva, A. Oxidative stress and some antioxidant system in acid rain-treated bean plants: Protective role of exogenous polyamines. Plant Sci. 2000, 151, 59-66. [CrossRef]

Sample Availability: Samples of the compounds are not available from the authors. 